cadio-scaphoid joint discoloured, and I therefore removed the scaphoid bone as well. The growth was strictly confined to the radius and to its lower end, not extending more than two inches up the shaft. It is now four months since th operation.

Cambridge.

\section{AN AFFECTION OF THE FIRST PHALANGEAL JOINT OF THE HAND.}

\section{By E. DoNaldson, B.A. T.C.D., L.R.C.S. IREL.}

IT sometimes happens when the hand is closed and an attempt is made to open it that one of the fingers remains in a state of fixed flexion with the tip almost touching the palm. The fault lies in the first phalangeal joint. The patient has to use the other hand to raise the finger into the straight position. A slight snap in the joint mentioned may be felt at the time of extension. The finger after reduction can be fexed and extended freely. The trouble is apt to return. The joint does not swell and, with the exception of this liability to get "stuck," presents no apparent abnormality. This little ailment is somewhat annoying to the patient, though it is not painfai. It appears to be rare. I have seen only one case. Mr. Jonathan Hutchinson has described three others, ${ }^{\perp}$ I do not know if any one else has written on the subject. So far, the affection has been found either in the ring or middle finger, and it may be found on one side or on both. It may be recovered from. Up to this it has not been found in anyone under fifty years of age. In the case observed by myself, which is published in $\mathrm{Mr}$. Hutchinson's "Archives of Surgery" (vol. vii.), the flexed and fixed condition of the ring finger was most likely to occur when a firm grasp of anything was taken. The patient covid close and open the hand without any difficulty if she did not aitempt to grasp anything firmly. This, although a trivial ailment, is a, very interesting one. The joint affected is the first phalangeal, which has most to do with flexion of the inger. I think a sabluxation of this joint occurs when the finger becomes fixed and flexed. The histories of the patients suggest that senile or rheumatic changes act as predisposing causes.

Londonderry.

\section{A CASE OF WOOL-SORTERS' DISEASE.}

\section{By Albert E. TUnstali, L.R.C.P., L.R.C.S. EdiN.}

THE following case of wool-sorters' disease occurred recently at Denholme. The patient was a man, aged forty. swo years, who had been engaged for several weeks sorting mohair at a factory where two men had died from wool-sorters' disease about eight months previously. He left his work at noon on Saturday, Jan. 2nd, 1897, apparently in hix usual health. Upon rising from bed about 9 A.M. on the Sunday morning, having slept well through the night, he complained of headache, localising it in the centre of the forehead. This pain became worse, so that about 11 A.M. he went back to bed and remained there until 4 P.M., when he again rose and had a cup of tea, but could not eat. $\mathrm{He}$ returned to bed about 7 P.M., the pain being not less severe. He had a restless night, being quite unable to sleep. During Monday the headache eased a little, but he commenced to feel a difficulty in breathing and had a slight cough. He then vomited what appeared to be a large clot of blood very dark in colour. That night he again had no sleep. During the early part of Tuesday he seemed to be easier. I saw the patient for the first and only time about 5 P.M. on this day (Jan. 5 hh). He then complained of headache, but said it was not severe. He had had no sleep since Saturday night, and also had taken no food since then. The patient's chief complaint, however, was that he had difficulty in getting his breath, saying, "There is something here," at the same time striking his hand upon the front of the chest over the upper part of the sternum. He had a slight cough, with expectoration of clear, rather frothy phlegm. His breathing was not laboured. His face had a dusky hue, and a somewhat careworn expression. The patient anxiously inquired what his illness was, and whether I thought it was

\footnotetext{
1 Archites of Surgery, vol. vi., p. 392, and vol. vii., pp. 54 and 380 .

owing to his work. The temperature was then $100.4^{\circ} \mathrm{F}$. and his pulse was 86 per minute. The heart sounds were normal, and examination of the lungs only revealed signs of slight congestion. He could converse freely and his case did not appear to be near its end. However, the difficulty of breathing increased and he expired rather suddenly and very quietly five minutes before midnight. The patient had been quite conscious and able to talk to his friends up to within five minutes of his death. I saw the body thirteen hours after death ; the face, neck, chest, and arms were then of a black-red colour, the legs retaining their natural white colour. The face was also swollen. The body still felt warm and post-mortem rigidity had not set in. By the next day the colour had slightiy faded in the face.

I am sorry that no post-mortem examination was made, as the friends of the deceased conld not be prevailed on to give their consent and the coroner did not order one. The insidious onset of the illness and the absence of grave symptoms all through were most noticeable. The friends did not feel alarmed until the patient vomited on the Monday night, and then, owing to my living at a distance of three miles, they decided to wait until the next morning before serding for me.

Thornton, Yorks.

\section{a}

or

\section{HOSPITAL PRACTICE, BRITISH AND FOREIGN.}

Nulla antem est alia pro cèrto noscendi via, nisi quamplurimas et morborum et dissectionum historias, tum aliorum tum proprias collectas habere, et inter se comparare.-MongAGNI De Sed. et Caus, Morb., habere, et inter se
lib. iv. Brocemium.

\section{SEAMEN'S HOSPITAI, GREENWICH.}

A CASE OF TETANUS TREATED WITH TIZZONI'S ANTITOXIN; RECOVERY

(Under the care of Mr. G. R. TuRner.)

We publish this week the notes of another case of tetanus treated with antitoxin, and our readers will recognise in it a type of the successful treatment of which more than one has recently been published-a young patient, a prolonged period of incubation, and slow development of symptoms. The case was by no means acute. The only example of the successful treatment of tetanus by the antitoxin serum which we were able to bring before our readers last year in the Mirror of Hospital Practice was a somewhat similar one. ${ }^{1}$ It was the case of a boy, aged seventeen years, who had shot bimself in the left hand. Stiffness of the jaw supervened on the twelfth day. Two days later antitoxin was given and the boy was convalescent in three weeks. The opinion of those watching this case as to the relative value of the serum and chloral hydrate is very striking. For the notes of this case we are indebted to Mr. E. Darbyshire, house surgeon.

On Aug. 31st, 1896, a boy, aged thirteen years, was admitted to the Seamen's Hospital, Greenwich, suffering from tetanus. The source of the infection was a wound influcted by a rusty nail which the lad had trodden on about three weeks previously. At the time of admission there was a scar on the sole of the left foot with quite a healthy appearance, there being a scab over part of it, but no discharge. The patient first noticed his mouth feeling stiff and experienced some difficulty in opening it on the 26 th, or about fourteen days after the injury. When the patient was brought to the hospital risus sardonicus was well marked and the teeth could not be separated more than a quarter of an inch. There was also slight stiffiness of the neck. The parents had not noticed any "spasms." On the day after admission the back was stiff and the stiffness of the neck had increased. No convulsive movements of the limbs occurred. The boy was given ten grains of bromide of potassium and five grains of chloral hydrate every eight hours. On Sept. 2nd spasms of the arms were noticed, but these were not severe. At 9 P.M. on this date twenty grains of Tizzoni's serum were injected into the abdominal wall. No 